\title{
RET Rearrangement Analysis
}

National Cancer Institute

\section{Source}

National Cancer Institute. RET Rearrangement Analysis. NCI Thesaurus. Code C157195.

A procedure used to detect and identify rearrangements involving the RET gene. 